\title{
STRUCTURAL LEAF CHANGES IN TREES AROUND A SUBWAY AIR DUCT ${ }^{1}$
}

Renato de Aragão Ribeiro Rodrigues², Vanderson Corrêa Vaz ${ }^{3}$, Alice $\mathrm{Sato}^{4}$, Rosani do Carmo de Oliveira Arruda $^{5}$, Wagner Antonio Chiba de Castro ${ }^{6}$ e Dalva Maria da Silva-Matos ${ }^{7}$

\begin{abstract}
While a number of papers have shown that subway systems have an impact on the air quality through the release of particulate matters, no information about the impact of such particles on tree attributes is available. Tree leaves from three different species from the exit side of a subway station in Rio de Janeiro, Brazil, were more asymmetrical than leaves from the entrance side. This leaves also presenting changes in leaves cuticle and chlorophyll content.
\end{abstract}

Keywords: Air pollution; Fluctuating asymmetry; Subways.

\section{ALTERAÇÕES NA ESTRUTURA DE FOLHAS EM ÁRVORES EM TORNO DE DUTOS DE AR DE METRÔ}

\begin{abstract}
RESUMO - Vários artigos vêm mostrando que os sistemas de metrô causam impactos na qualidade do ar, através da emissão de material particulado. No entanto, não há informações disponíveis sobre o efeito desse impacto na vegetação. Folhas de árvores de três espécies diferentes localizadas do lado da saída de dutos de um metrô no Rio de Janeiro, Brasil, se mostraram mais assimétricas do que as de árvores localizadas do lado da entrada. Essas folhas também apresentaram alterações na camada de cera epicuticular e no conteúdo de clorofila.
\end{abstract}

Palavras-chave: Poluição; Assimetria flutuante; Metrôs.

\section{INTRODUCTION}

Some studies have shown that subway systems impact the air quality through release of particulate matters. The concentration of particles in subway stations and tunnels may be due to the wheel material and the breaking system. The higher toxicity, in comparison to outdoors, is related to the increased concentration of Mn (Nieuwenhuijsen et al. 2007), Fe and $\mathrm{Cu}$ (Murruni et al. 2009).

Changes on leaf morphology, anatomy or physiology as a consequence of different pollutants have been widely reported in the literature (Seyyednejad et al. 2011). Through the analysis of their performance we can detect the impacts of environmental pollution on organisms, and potentially estimate the consequences of long-term exposition to harmful chemicals, that, in some cases, cannot be detected by measuring even a wide range of physiochemical variables (Pöykiö et al. 2005).

Few decades ago in Copacabana, the major tourist region of Rio de Janeiro city, a subway line was set up under the Parque Estadual da Chacrinha (22 $57^{\circ} 46^{\prime \prime} \mathrm{S}$, $\left.43^{\circ} 10^{\circ} 48^{\prime \prime} \mathrm{W}\right)$, one of the largest remnants of the Atlantic Rain Forest in that region. In order to exchanging the air from the tunnel, a ventilation duct was installed within the reserve. As a consequence, tree trunks became dark nearby this building, on the side where the air from the tunnel is released. Considering that plants

\footnotetext{
${ }^{1}$ Recebido em 30.05.2014 aceito para publicação em 15.04.2015

22Embrapa Solos, Rio de Janeiro, RJ - Brasil. E-mail: >renato.rodrigues@embrapa.br>.

${ }^{3}$ Prefeitura Municipal de Angra dos Reis, RJ - Brasil. E-mail: <vandersonvaz992@gmail.com>.

${ }^{4}$ Universidade Federal do Estado do Rio de Janeiro, Departamento de Ciências Naturais, RJ - Brasil. E-mail:<alicesato@unirio.br>.

${ }^{5}$ Universidade Federal do Mato Grosso do Sul, Departamento de Biologia, MS - Brasil. E-mail: <rosaniarruda@gmail.com>. ${ }^{6}$ Universidade Federal da Integração Latino- Americana, Instituto Latino- Americano de Ciências da Vida e da Natureza, PR - Brasil. E-mail: <wagner.castro@unila.edu.br>.

${ }^{7}$ Universidade Federal de São Carlos, Departamento de Hidrobiologia, SP - Brasil. E-mail: <dmatos@ufscar.br>.
}

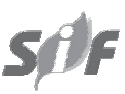

Revista Árvore, Viçosa-MG, v.39, n.3, p.417-421, 2015 http://dx.doi.org/10.1590/0100-67622015000300001 
are useful bioindicators (SEYYEDNEJAD et al., 2011), we hypothesize that leaves of trees occurring in the opposite sides of the ventilation duct are morphological and physiologically different in response to distinct in their air quality.

\section{MATERIALAND METHODS}

In order to validate the comparisons between leaves, we previously certified that (1) there were no other differences between the two sides of the duct that could be affecting the vegetation, (2) the same species should be found in both sides to be compared, (3) the distance of individuals up to the air duct should be similar between the entrance and exit sides (H"10 apart). Therefore we found two individuals (one in each side of the duct) of three tree species which fills the validations two and three: 1) Ficus elastica Roxb. (Moraceae), Syzygium jambolanum (Lam.) DC. (Myrtaceae) and Guarea guidonia (L.) Sleumer (Meliaceae). For the analysis of fluctuating asymmetry in leaves we sampled 20 intact shaded and fully-developed leaves from each individual of each tree species. Leaves were immediately taken to the laboratory and digitized in a scanner previously standardized to avoid bias in the measurements. From each one we measured the total leaf area and the area of the left (WL) and right (WR) sides of the leaf, from the midrib to the outer leaf margin. The fluctuating asymmetry (FA) was defined as follows (PALMER; STROBECK, 1986): FA = var [WL - WR]. Because the assumptions for using the parametric test were not filled the results of FA, the total area and from each side of the leaf were compared through the Mann Whitney U-test. (ZAR, 1984). Following the same procedure for leaf choice, three leaves from individuals located in both sides of the air duct were collected, fixed in F.A.A. $70 \%$ for $48 \mathrm{~h}$ and preserved in 70\% ethanol (JOHANSEN, 1940). For scanning electron microscopy (SEM) observations, 8 segments of each fixed leaf $\left(0.5 \mathrm{~cm}^{2}\right)$ were dehydrated in ethanol series, submitted to critical point drying with $\mathrm{CO}_{2}$ (Leica EM CPD-030), mounted on stubs and coated with a thin layer of gold. Samples were analyzed with a DSM-940 Zeiss scanning electron microscopy. In order to remove wax and confirm its presence, the sections of dehydrated leaves were boiled three times in chloroform for 10 seconds. Following the previous procedure for leaf choice, we sampled fifteen shadow mature leaves from each individual, from both sides of the air duct. To estimate the leaf chlorophyll content the samples were cutted in three small disks measuring $467 \mathrm{~mm}^{2}$ and putted into glass tubes containing $5 \mathrm{~mL}$ of DMSO (dimethyl sulfoxide). These samples were then kept in a water bath $\left(60^{\circ} \mathrm{C}\right)$ for 24 hours. After that, we performed a spectrophotometric analysis (using Spectronic Genisys II - Milton Roy device) using the following wavelengths: 450, 649, 665 and $750 \mathrm{~nm}$ (WELLBURN, 1994). This experiment was carried out during the dry season (April) and repeated in the rainy season (October). The results from individual trees from each side were compared by the Mann Whitney U-test.

\section{RESULTS}

We found significant differences between leaves of Guarea guidonia collected on the entrance side and those collected on the exit side of the air duct. Leaves from the entrance side were larger $(93.79 \pm 17.67$ $\mathrm{mm})$ than the leaves from the exit side $(82.96 \pm 14.32$ $\mathrm{mm})(\mathrm{U}$-prime $=157, \mathrm{p}=0.045)$. Leaves of Ficus elastica and Syzygium jambolanum located close of the exit side were slightly larger than those located at the entrance side (Table 1). In relation to the leaf asymmetry we verified that, in general, leaves at the exit side were more asymmetrical than leaves at the entrance side (Table 1).

The results for leaves of Ficus elastica collected at the exit side revealed that the epidermis is covered by a smooth but degradated wax layer (Fig. 1a and b). In Guarea guidonia the cuticle surface is papilous and covered by a smooth layer, its ornamentation is less developed and the leaves exhibit numerous particles (Fig.1 c and d). Leaves of Syzygium jambolanum at the entrance side have a wax layer with small ornamentations producing a granulated aspect. On the leaves at the exit side the wax layer presented less developed (Fig.1 e and f).

The results indicated that the chlorophyll contents exhibited some variations between the rainy and the dry season. Nevertheless we found significant differences between leaves collected in the two sides of the air duct in both seasons. In the rainy season, we observed differences on the chlorophyll content by the leaves of Syzygium jambolanum and Ficus elastica, whitch have greater values of chlorophylls $a$ and $b$ at the exit side. 
Table 1 - Mean values (mean \pm SD) of fluctuating asymmetry values (FA) and total area (TA, $\mathrm{mm}^{2}$ ) of leaves for the three studied species. *Indicates significant difference for comparisons on entrance and exit sides of subway air duct $(\mathrm{p} \leq 0.05)$.

Tabela 1 - Valores médios (média \pm desvio-padrão) dos valores de assimetria flutuante (FA) e área total (TA, $\left.\mathrm{mm}^{2}\right)$ de folhas das três espécies estudadas. * Indica diferenças significativas para comparações entre a entrada e a saída dos dutos de ar do metrô ( $p \leq 0.05)$.

\begin{tabular}{|c|c|c|c|c|}
\hline & & Ficus elastica & Syzygium jambolanum & Guarea guidonia \\
\hline & Total & $112.521 \pm 21.55$ & $28.852 \pm 4.623$ & $43.935 \pm 8.855$ \\
\hline & Entrance & $108.986 \pm 14.065$ & $27.531 \pm 4.662$ & $40.318 \pm 8.627$ \\
\hline \multirow[t]{3}{*}{ FA } & Exit & $116.057 \pm 27.154$ & $30.173 \pm 4.335$ & $46.551 \pm 8.563$ \\
\hline & U-Prime / p-valor & $125 / 0.6041$ & $148 / 0.1409$ & $157 / 0.0449^{*}$ \\
\hline & Total & $227.414 \pm 44.091$ & $56.947 \pm 9.06$ & $88.373 \pm 16.733$ \\
\hline \multirow[t]{3}{*}{ TA } & Entrance & $222.242 \pm 30.016$ & $54.453 \pm 9.287$ & $93.787 \pm 17.666$ \\
\hline & Exit & $232.587 \pm 55.395$ & $59.442 \pm 8.394$ & $82.965 \pm 14.324$ \\
\hline & U-Prime / p-valor & $122 / 0.6936$ & 154 / 0.0852 & $162 / 0.0401 *$ \\
\hline
\end{tabular}
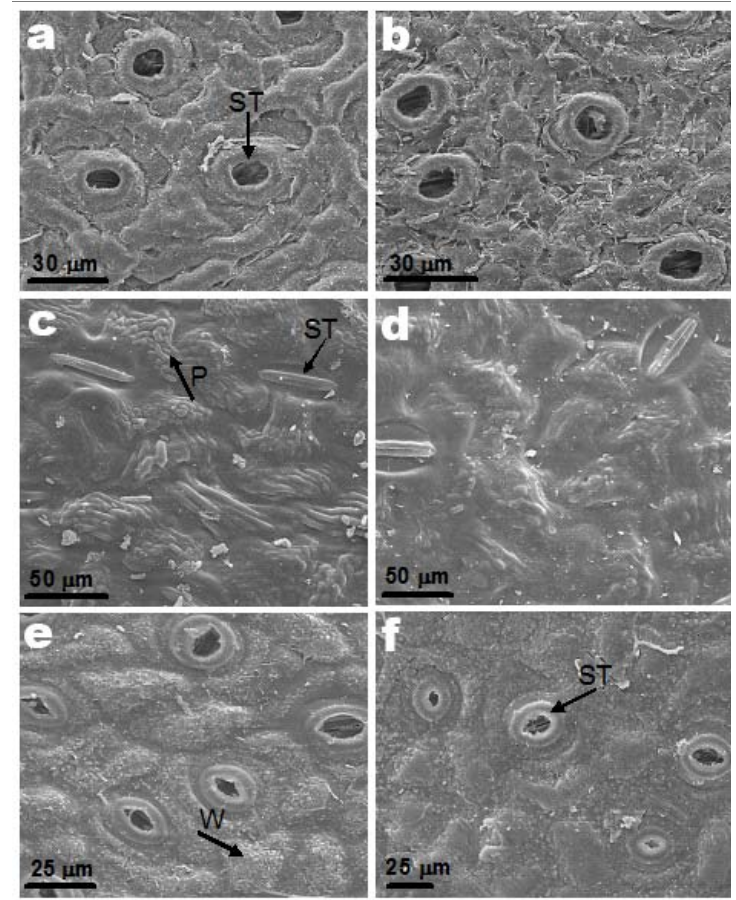

Figure 1 - Abaxial leaf surfaces in frontal view. Figures. b, $\mathrm{d}$ and $\mathrm{f}$ : leaves from entrance side of subway air duct. Figures. a, c and e: leaves from exit side. P: papillae, several per cell. ST: stomata. W: wax layer over epidermal cells. a-b. Ficus elastica. c-d. Guarea guidonia e-f. Sizygium jambolanum.

Figura 1 - Superfície inferior das folhas em vista frontal. Figuras b, d e f: folhas do lado da entrada do duto de ar do metrô. Figuras a, c e e: folhas do lado da saída. P: papilas, várias por célula. ST: estômatos. W: camada de cera sobre células epidérmicas. $a-b$. Ficus elastica. $c$-d. Guarea guidonia e-f. Sizygium jambolanum.
We obtained significant differences on the chlorophyll a and b content by leaves collected during the dry season of all species, with exception from Guarea guidonia. This species showed the highest values of chlorophyll $a$ and $b$, and also of carotenoids in leaves collected from the exit side. However, differences from the entrance and exit side were more conspicuous for leaves collected in the rainy season: leaves from all the trees located in the exit side showed higher values of chlorophyll $a$ and $b$, and also of carotenoids (Table 2).

\section{DISCUSSION}

The impact of pollution on leaves has been already described for other tropical tree species. In Cubatão, industrialized region in São Paulo, Brazil, seedlings of Tibouchina pulchra Cogn. (Melastomataceae) showed alterations in plant height, biomass, net photosynthesis, growth rate and leaf chemistry in response to environmental pollution (MORAES et al., 2000). Leaves of Eugenia uniflora L. (Myrtaceae) and Clusia hilariana Schlecht. (Clusiaceae) occurring naturally in Brazilian sandy zones (restingas) showed many signs of injury when submitted to simulated acid rain: alterations on wax layer, epidermal and mesophyll cells (SILVA et al., 2005).

Changes on leaf structure may cause damage to physiological processes and compromise the survival of the species in their natural environments (Gratani et al. 2000). The cuticle which covers the aerial parts of a plant protects the plant against biological, physical and chemical constraints. Chemically, the cuticle is 
Table 2 - Mean values (mean \pm SD) of leaf concentrations of chlorophyll a, chlorophyll $\mathrm{b}$ and total carotenoids for the three studied species. *Indicates significant difference for comparisons on entrance and exit sides of subway air duct $(\mathrm{p} \leq 0.05)$.

Tabela 2 - Valores médios (média \pm desvio-padrão) da concentração de clorofila a das folhas, clorofila b e carotenoides totais das três espécies estudadas. * Indica diferenças significativas para comparações entre a região da entrada e saída dos dutos de ar do metrô ( $p \leq 0.05)$.

\begin{tabular}{|c|c|c|c|c|c|c|}
\hline & \multicolumn{3}{|c|}{ Entrance side } & \multicolumn{3}{|c|}{ Exit side } \\
\hline & G. guidonia & S. jambolanum & F. elastica & G. guidonia & S. jambolanum & F. elastica \\
\hline & & \multicolumn{5}{|c|}{ First Sample (October) } \\
\hline Clorophyl a & $51.54 \pm 9.7$ & $24.98 \pm 6.64 *$ & $40.62 \pm 7.36^{*}$ & $58.1 \pm 8.78$ & $38.5 \pm 3.14^{*}$ & $52.92 \pm 5.6^{*}$ \\
\hline Clorophyl b & $25.02 \pm 4.4$ & $10.98 \pm 3.68^{*}$ & $19.78 \pm 3.08^{*}$ & $28.2 \pm 3.8$ & $15.38 \pm 3.3^{*}$ & $23.78 \pm 1.4^{*}$ \\
\hline \multirow[t]{2}{*}{ Carotenoids } & $3.4 \pm 0.50$ & $1.18 \pm 0.86$ & $2.94 \pm 0.38^{*}$ & $3.78 \pm 0.28$ & $1.32 \pm 0.68$ & $3.18 \pm 0.76^{*}$ \\
\hline & \multicolumn{6}{|c|}{ Second Sample (April) } \\
\hline Clorophyl a & $25.04 \pm 3.9^{*}$ & $40.88 \pm 2.54$ & $44.74 \pm 1.08$ & $40.02 \pm 1.74 *$ & $36.02 \pm 3.2$ & $37.98 \pm 7.98 *$ \\
\hline Clorophyl b & $9.28 \pm 3.78 *$ & $22.7 \pm 4.46^{*}$ & $14.12 \pm 0.68$ & $19.38 \pm 2.20 *$ & $3.66 \pm 1.94^{*}$ & $12.6 \pm 3.4$ \\
\hline Carotenoids & $1.72 \pm 0.68$ & $2.98 \pm 0.16^{*}$ & $3.3 \pm 0.10^{*}$ & $2.7 \pm 0.16$ & $1.2 \pm 0.22 *$ & $2.78 \pm 0.34 *$ \\
\hline
\end{tabular}

always characterized by insoluble polymeric cutins which constitute the framework of the membrane and soluble waxes deposited on the surface as epicuticular wax and embedded within the cutin matrix as cuticular wax. In the simulated acid rain experiment, leaves of Eugenia uniflora L. (Myrtaceae) and Clusia hilariana Schlecht. (Clusiaceae) presented necrosis predominantly in the adaxial surface, which facilitates the penetration of pollutants through the cuticle (SILVA et al., 2005). Although no direct evidence has been found, physiological and morphological differences observed in this study might be related to leaf surface changes between leaves from both sides of the air duct.

Leaves of Guarea guidonia showed the most evident differences between the entrance and exit side through their smaller size, the presence of pollution particles within their cells, the greater amount of chlorophyll $a$ and $b$, and carotenoids in the leaves collected at the exit side. Since this is a recent impact (the subway was inaugurated in 1998), it is possible that the construction of the subway duct hasn't yet caused enough impact to alter the morphology of the leaves of Ficus elastica and Syzygium jambolanum, larger and apparently more resistant species (especially Ficus elastica).

In urban areas, beyond the problem of deforestation and forest fragmentation, pollution is one threat to the remnant biological diversity. Although subways are considered an integral part of mass transit and contribute to the sustainability of urban environment, this study verified that trees around subway stations are continuously exposed to pollutants that are released from its tunnel. Our result contrast with the findings of Fujii et al. (2007) with argue that indoor subway stations act as pollutants receptor from the external environment. These morphological, anatomical and physiological founds changes support the visual observations that the subway air duct is causing an environmental damage of a magnitude not yet estimated.

\section{CONCLUSION}

Trees are good biomonitors for air pollution and can be widely used for this kind of study.

The pollution released by the subway line through the ventilation duct is harmful to the plants and can threaten the survival of the species in their natural environments.

Due to this pollution the leaves of trees occurring in the opposite sides of the ventilation duct are morphological and physiologically different in response to distinct in their air quality.

Air quality around subway air ducts should be also monitored in parallel to the subway tunnels and stations.

The responsible company should take some steps, such as the installation of air filters and the conservation of the area. This requires a better supervision of the park by the local government and further studies about the impacts of pollution outside stations and tunnels.

Revista Árvore, Viçosa-MG, v.39, n.3, p.417-421, 2015 


\section{ACKNOWLEDGEMENT}

We would like to thank Dra Vera Bongertz (IOC/ FIOCRUZ) for insightful comments and English revision, Dr. Leandro Cardoso for help in Guarea guidonia identification and CNPq (National Counsel of Technological and Scientific Development) for financial support.

\section{REFERENCES}

FUJII, R.K.; OYOLA, P.; PEREIRA, J.C.R.; NEIDE, A.S. CACAVALLO, R.C. Air pollution levels in two São Paulo subway stations. Highway and Urban Environment, v.12, p.181-190, 2007.

GRATANI, L.; CRESCENTE, M.F.; PETRUZZI, M. Relantionship between leaf life-span and photosynthetic activity of Quercus ilex in polluted urban areas (Rome). Environmental Pollution, v.110, n.1, p.19-28, 2000.

JOHANSEN, D.A. Plant microtechinique. New York: McGrow-Hill Book, 1940. 523p.

MORAES, R.M.; DELITI, W.B.C.; MORAES, J.A.P.V. Respostas de indivíduos jovens de Tibouchina pulchra Cogn. à poluição aérea de Cubatão, SP: fotossíntese liquida, crescimento e química foliar. Revista Brasileira de Botânica, v.23, n.4, p.443-449, 2000.

MURRUNI, L.G., SOLANES, V., DEBRAY, M., KREINER, A.J., DAVIDSON, J., DAVIDSON, M., VAZQUEZ, M., OZAFRAN, M Concentrations and elemental composition of particulate matter in the Buenos Aires underground system.

Atmospheric Environment, v.43, p.4577-4583, 2009.

NIEUWENHUIJSEN, M.J.; GÓMEZ-PERALES, J.E.; COLVILE, R.N. Levels of particulate air pollution, its elemental composition, determinants and health effects in metro systems.

Atmospheric Environment, v.41, p.7995-8006, 2007.

PALMER, A.R.; STROBECK, C. Fluctuating asymmetry, measurement, analysis, patterns. Annual Review of Ecology and Systematics, v.17, p.391-421, 1986.

PÖYKIÖ, R.; PERÄMÄKI, P.; NIEMELÄ, M. The use of Scots pine (Pinus sylvestris L.) bark as a bioindicator for environmental pollution monitoring along two industrial gradients in the Kemi-Tornio área, northern Finland. International Journal of Environmental Analytical

Chemistry, v.85, n.2, p.127-139, 2005.

SEYYEDNEJAD, S.M.; NIKNEJAD, M.; KOOCHAK, H. A review of some different effects of air pollution on plants. Research Journal of Environmental Sciences, v.5, p.302-309, 2011.

SILVA, L.C., OLIVA, M.A., AZEVEDO, A.A., ARAÚJO, J.M., AGUIAR, R.M.

Micromorphological and anatomical alterations caused by simulated acid rain in Restinga plants: Eugenia and Clusia hilariana. Water, Air, Soil and Pollution, v. 168, n.1, p.129-143, 2005.

WELLBURN, A.R. The spectral determination of chlorophylls a and b, as well as total carotenoids, using various solvents with spectrophotometers of different resolution. Journal of Plant Physiology, v.144, p.307-313, 1994.

ZAR, J.H. Biostatistical analysis. $2^{\text {nd }}$.ed. New Jersey: Prentice Hall, 1984. 736p. 